\title{
Preserving old, traditional varieties of pears in n.w. bohemia
}

\begin{abstract}
Between 2006 and 2008 as part of the revitalization of road alley was created pomological study and identification of the original, old pear varieties planted in the 18th century in the town of Kadan (N.W.Bohemia). In this pear for historically significant areas have been identified more than 50 types of pear local varieties and landraces. From this amount of varieties have more significant representation 10 varieties, including local varieties such as Koporecka, Salzburg and Solanka expect these were discovered other old varieties like Giffardova, Clappova and Avranska.
\end{abstract}

Keywords: pear-trees, P. communis subsp. communis, germplasm on farm, pomology study, maintenance in natural place
Volume 2 Issue 2 - 2018

\author{
Frajt J, Krska B, Zajicova Z, Zajic J, Reznícek \\ $\checkmark$ \\ Department of Horticulture, University of Mendel, Czech \\ Republic
}

Correspondence: Krska B, Department of Horticulture, University of Mendel, Czech Republic,

Email borokrska@gmail.com

Received: September 9, 2017| Published: March 23, 2018

\section{Introduction}

From the 14th to the 16th century, fruit growing in Kadaň was ranked third after hops and wine grapes on the basis of the area it occupied and its economic importace. ${ }^{1}$ Confirmation of this fact can be found in the carvings on the doors of the Kadaň town hall which date from 1713- It illustrates the most important agricultural products of that time: hops, grapes and pears. In the eighteenth century they started to expand fruit growing in the surrounding country, in fenced-off orchards and in back gardens. They also began to grow new varieties imported from abroad, mainly from France. At the end of the eighteenth century the largest fruit growing areas were to be found near the estates of Ahníkov-Prunéřov and Kláštěrec nad Ohří and the villages of Poláky and Lužice. ${ }^{2}$ According to ${ }^{2}$ in 1860 , 13,806 fruit trees were recorded in the parish of Tušimic in Lužice. In 1860 they organised a public display of the fruit being grown, which aroused general admiration and led to it being repeated every two years. In 1863, in the Kadaň district, the total yield of fruit from 294,073 trees was 17,091 measures worth 35,597 gold reces. ${ }^{2}$ The following traditional varieties of apples grown in the Kadaň region were recognized as being excellent: Peregrine, Bergamot, Meissen, Rozmarýnky, Bamberské, Vinné (cider-apple), Rennet, Russet, Jahodové, Malinové, Citronové, Ananasové and Skořicové, among others. $^{3}$ Among pears, there were varieties known as Máslovky, Statinské, Knížecí, Císařské, Salzburg, Majdalenky and Muscat. In addition, several varieties of both sweet and sour cherries, as well as plums, were grown too. Apricots, peaches and mirabelle plums were also grown in small quantities in back gardens. Towards the end of the nineteenth century there was a radical decline in the cultivation of apples in the western half of Kadaň distrikt. Both orchards and roadsides, principály declined due to the destruction caused by a severe frost in 1871, which wiped out whole orchards. Pears, however, proved to be more resistant, so they were used to plant up the gaps and by 1940 pears occupied up to $90 \%$ of the lower parts of the Kadañ distrikt. ${ }^{4}$ It would be particularly beneficial to improve the care and maintenance of pear trees at roadsides, or in existing orchards. In the past, pear varieties such as Koporečka a Solanka were highly regarded for their quality and much sought after.

\section{Materials and methods}

The current situation has prompted the residents of Chbany to start looking after these varieties, this pear genepool, not just by recording and monitoring the different varieties but also by pruning the existing trees, replacing dead trees and planting new areas. With the continued cooperation with Mendel University in Brno and its Horticultural Faculty in Lednice, and in close cooperation with the environmental officers of Kadan town council, this extensive and difficult phase of the project is being tackled. The research and preserving work were carry out in following steps.

1. In 2006 - trainning of pruning

- renew pruning

- $\quad$ pomological identification and mapping

- $\quad$ selection of mater trees and budding

2. In 2007 - renew pruning

- $\quad$ pomological identification and mapping

- growing of sampling material in the nursery

3. In 2008 - renew pruning

- $\quad$ pomological identification and mapping

- $\quad$ planting two years old sampling material as alley around the new road between Nechranice dam and Chbany village - 450 trees

All pomological identification was made by Professor Řezniček with the help of pomological atlases and books. ${ }^{3-6}$

\section{Results}

In the first stage(2006-2008), samples of fruit were collected for precise identification and for establishing guidelines for the appropriate conservation of these varieties for future cultivation and use. In the second stage, fresh growth was collected and used for grafting onto pear seedling rootstocks for nursery cultivation and the production of new planting material (there are now 108 different genotypes grown by the Horticultural Faculty of Mendel University in Brno). This work was preceded by, severe spring pruning in order to rejuvenate the trees, shape the new growth, and also provide the grafting material. The mapping and recording of these pear varieties, and the collection of propagating material covered $9 \mathrm{~km}$ of village streets, and $15 \mathrm{~km}$ of grade 2 (no. 223) and grade 3(no. 3/225) roads, 
all in the Ústecky region. In 2006 the entire work was organised and financed by the village of Chbany.

These varieties were categorised as follows:

Predominant varieties: Koporečka, Clappova, Hardyho, Solanka, Avranšská

Frequently occurring varieties: Š́lenka, Solnohradska, Kozačka Stuttgartská, Giffardova, Muškatelka šedá

Infrequently occurring varieties: Děkanka, Robertova, Monchalardova („Rumovka“), Merodova „Křivice, Dielova, Napoleonova, Hardenpontova, Amanliská, Pstružka, Lucasova, Drouardova, Děkanka červenošedá, Nelisova zimní, Williamsova

Pomological notes on one of the predominant variety: Koporečka - this is a well-known Czech variety, introduced at the end of the 18th century, probably in Koporečí na Mostecku, where it is widely distributed. It ripens in November and can be stored until the Spring. It is one of the favourite varieties in Northwest Bohemia. It is commonly grown along roadsides.

\section{Conclusion}

In 2008 an application for a grant was made to the Ústí nad Labem regional authorities, to support the renovation of agricultural land as part of the general programme aimed at helping the development of farming and rural areas in the Ústí region during the years 2007 and 2008. Thanks to their support, the villages were given the means to carry out this work and complete the whole excercise. As the part of the revitalization of the road alley, monitoring of varieties emerging from the 18th century was carried out at the same time in 2006-2008. More than 50 varieties of local, traditional and world were found. Five or 10 varieties dominated this genotype set as shown in Table 1.

Table I An overall distribution of pear varieties in the assessed region

\begin{tabular}{ll}
\hline Summer cultivars & cultivar distribution in \% \\
\hline I. Clappova & 33,92 \\
2. Williamsova & 8,92 \\
3. Merodova & 8,92 \\
4. Š́dlenka & 5,35 \\
5. Solanka & 3,57 \\
6. Muškatelka turecká & 1,78 \\
7. Solanka & 1,78 \\
& Total $64,29 \%$ \\
Autumn cultivars & 10,71 \\
8. Hardyho & 8,92 \\
9. Charneuská & 1,78 \\
10. Boscova & 1,78 \\
I1. Solisburyova & 1,78 \\
12. Esferenova & 1,78 \\
I3. Amanliská & \\
\hline
\end{tabular}

\section{Acknowledgements}

This work was financially supported by the regional authorities of Ústí nad Labem, as part of a general programme aimed at helping the development of farming and rural areas in the Ústí region during the years 2007 and 2008 .

\section{Conflict of interest}

The author declares no conflict of interest.

\section{Apendix}

Picture of traditional pear cultivar "Koporečka".

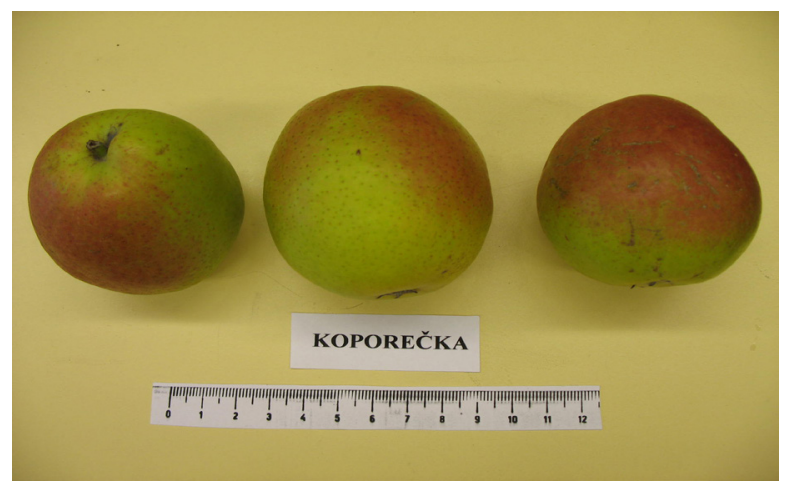

\section{References}

1. Buchtova I. Fruit - Situation and Outlook Report of the Ministry of Agriculture of the Czech Republic, Mze. 2006;68.

2. Anonymus: Archives of the City of Kadan. Kadan District Office and Regional Literature. 1915.

3. Suchy F. Moravian fruits Czech Agricultural Council of Moravian Margrave. Brno. 1905;447.

4. Cerník B, Bocek O, Vecera L. Small pomology 2 - pears, Mala zahradnicka kniznice. Praha. 1969;221.

5. Koloc R. Wir zeigen Birnensorten und werten deren Eigenschaften. Neumann Verlag. 1958

6. Muhl F. Alte und neue Birnensorten Quitten und Nashi Obst und Gartenbauverlag Munchen. 3.Auflage. 2004. 